\title{
ОСОБЕННОСТИ КОММУНИКАТИВНОЙ СФЕРЫ МЛАДШИХ ШКОЛЬНИКОВ
}

\author{
Симакова К.А. \\ Филиал Ставропольского
}

государственного педагогического института в г. Буденновске,

Ставропольский край, Российская Федерация

ЭВ статье обсуждается проблема важности общения в процессе развития младших школьников. Представлен небольшой обзор исследований по проблемам коммуникативных трудностей. Рассмотрень результаты психодиагностического исследования особенностей общения детей младшего школьного возраста.

Ключевые слова: младшие школьники; общение; коммуникативные особенности; направленность личности в общении.

\section{FEATURES OF THE COMMUNICATIVE SPHERE OF YOUNGER STUDENTS}

\section{Simakova K.A.}

Branch of Stavropol state pedagogical Institute in Budennovsk, Stavropol region, Russian Federation

The article discusses the importance of communication in the development of younger students. A short review of studies on the problems of communication difficulties is presented. The results of a psychodiagnostic study of the features of communication among children of primary school age are considered.

Keywords: younger schoolchildren; communication; communication characteristics; the orientation of the personality in communication.

Полноценное общение очень важно для развития детей, что показано многочисленными исследованиями отечественных и зарубежных исследователей. Исследование проблемы возникновения трудностей и нарушений общения наряду с научным значением представляет практический интерес, поскольку нацелено, в конеч- 
ном счете, на решение многих психологических и педагогических вопросов, связанных с организацией эффективного обучения и воспитания детей младшего школьного возраста.

Проблеме общения детей посвятили свои исследования А.А. Бодалев, ЈІ.С. Выготский, Т.П. Гаврилова, А.Б. Добрович, Я.Л. Коломинский, А.Г. Ковалев, А.В. Мудрик, В.С. Мухина, Н.П. Царева и др., обращая особое внимание на вопросы межличностного общения детей и аспекты изучения и преодоления трудностей их взаимодействия, устранения различных препятствий психологического и социального характера. Нарушения и трудности общения, коммуникативные барьеры исследовались также в работах Ф. Зимбардо, А.П. Егидеса, Е.В. Залюбовской, В.Н. Кунициной. Б.Д. Парыгина, Е.В. Цуканова и др. [2].

Коммуникативная компетентность является одним из базовых метапредметных универсальных учебных действий, которые необходимо формировать у младших школьников. Однако, возможности общения детей, в той или иной степени могут ограничиваться (блокироваться) трудностями различного характера и отрицательными (социально нежелательными) свойствами их личности [1]. Все это усугубляется тем фактом, что в современных условиях детям и подросткам гораздо проще общаться в социальных сетях и с помощью различных мессенджеров, чем вживую.

Таким образом, существование проблемных ситуаций в сфере общения младших школьников, существенно снижающих возможности их развития в школе, а также необходимость дельнейшей теоретической проработки путей и методов разрешения таких ситуаций, и определили проблему нашего исследования.

Целью нашего исследования был изучение особенностей общения детей младшего школьного возраста. С этой целью мы использовали следующие методики:

- Методика «Диагностика особенностей общения» (В.Н. Недашковский);

- Методика «Направленность личности в общении» (С.Л. Братченко).

Методика «Диагностика особенностей общения» (В.Н. Недашковский) [3] позволила нам выявить ряд особенностей коммуника- 
тивного потенциала школьников. Методика состоит из 24 парных утверждений и пяти вариантов ответов, с помощью которых испытуемый выбирает более соответствующее его представлениям о себе в процессе общения. Ответы испытуемых обрабатываются в соответствие с ключом и интерпретируются по целому ряду показателей. В своем исследовании мы взяли обрабатывали показатели только основных шкал, таких как: умение понимать собеседника; умение воспринимать и понимать себя (рефлексировать); умение строить межличностные границы; особенности посланий в общении.

Для удобства представления результатов, мы выделили два уровня развития данных особенностей (что согласуется с методикой): высокий и низкий. При этом в исследовании мы не использовали дополнительные показатели методики (проявление общей рефлексии в общении; проявление процесса эмпатии в общении; «адресность» в общении; адекватное понимание; создание межличностных границ в общении; проявление открытости в общении; процесс распределения внимания на всех участников общения; рефлексия мышления в момент общения; рефлексия сферы желаний в момент; рефлексия сферы чувств; рефлексия телесных ощущений), поскольку они не предусматривают возможность разделения по уровням.

По результатам диагностики особенностей общения детей по методике В.Н. Недашковского на констатирующем этапе можно отметить следующее: большинство учащихся четвертого класса показывают высокий уровень по всем показателям, однако от $30 \%$ до 42 \% детей по разным шкалам показали низкий уровень развития коммуникативных особенностей.

Методика «Направленность личности в общении» (НЛО - А) (С.Л. Братченко) [3] позволяет определить какая из шести коммуникативных направленностей (выделенных С.Л. Братченко) свойственны испытуемым: диалогическая направленность личности в общении; авторитарная направленность личности в общении; манипулятивная направленность личности в общении; конформная направленность личности в общении; альтероцентристская направленность личности в общении; индифферентная направленность личности в общении. 
Диагностика коммуникативной направленности показала, что меньше всего школьников проявляют индифферентную направленность (4\% школьников), при которой общение совершенно обесценивается и альтероцентристскую направленность (10\%), предполагающую ориентацию на цели и потребности партнера по общению в ущерб своим. Наиболее часто выбираемые школьниками позиции в общении (по 23\% испытуемых показали данные виды направленности) - это диалогическая направленность (предполагающее равноправное общение, основанное на взаимопонимании); авторитарная направленность (характеризующуюся эгоцентризмом и стремлением доминировать в процессе общения) и конформная направленность (ориентирующая на подражание и готовность отказаться от своей позиции в пользу партнера по общению).

Таким образом, проведенное диагностическое исследование показало, что в среднем у 37\% младших школьников отмечаются трудности в коммуникативной сфере и необходима организация психолого-педагогического сопровождения этих детей.

\section{Список литературы}

1. Даргевичене Л.И. Особенности личных взаимоотношений младшего школьника. М., 1971.

2. Общение и формирование личности школьника: опыт экспериментально-психологических исследований / Под ред. А.А. Бодалева. М., 1987.

3. Психологическая диагностика коммуникативного потенциала личности: методические рекомендации для студентов / Сост. Н. А. Зимина. Н. Новгород: ННГАСУ, 2015.

\section{References}

1. Dargevichene L.I. Osobennosti lichnykh vzaimootnosheniy mladshego shkol'nika. M., 1971.

2. Obshchenie i formirovanie lichnosti shkol'nika: opyt eksperimental'no-psikhologicheskikh issledovaniy / Pod red. A.A. Bodaleva. M., 1987.

3. Psikhologicheskaya diagnostika kommunikativnogo potentsiala lichnosti: metodicheskie rekomendatsii dlya studentov / Sost. N. A. Zimina. N. Novgorod: NNGASU, 2015. 